\title{
Posttreatment Effects of Castor Bean Oil and Heating in Treated Jabon Wood on Boron Leaching, Dimensional Stability, and Decay Fungi Inhibition ${ }^{1}$
}

\author{
Trisna PRIADI $^{2} \cdot$ Marini Dwi LESTARI ${ }^{2} \cdot$ Tekat Dwi CAHYONO ${ }^{3, \dagger}$
}

\begin{abstract}
Red jabon wood is a potential fast-growing species for veneer, furniture, and many other wood products, but its durability is very low. The purpose of this study was to investigate the effects of castor bean oil and heating on boron leaching, dimensional stability, and resistance to decay fungi in treated jabon wood. Red jabon wood was preserved with boron solutions containing $5 \%$ boron (boric acid, borax, or borax-boric acid). Following that, castor bean oil impregnation and heating were used as posttreatments. Furthermore, all the wood samples were tested in terms of leaching, dimensional stability, and resistance against Schizophyllum commune and Fomitopsis palustris fungi. This study discovered that boron compounds, castor bean oil, and heating treatments influenced the leaching, dimensional stability, and resistance of red jabon wood to decay fungi. The double impregnation of boric acid or borax and castor bean oil, followed by heating at $160^{\circ} \mathrm{C}$, significantly reduced water absorption and leaching while increasing the dimensional stability and resistance of red jabon wood against the two tested decay fungi.
\end{abstract}

Keywords: boron, castor bean oil, decay, dimensional stability, fungi, impregnation, red jabon

\section{INTRODUCTION}

\section{Anthocephalus macrophyllus (Roxb.) Havil (red ja-} bon) is one of the potential fast growing wood species for industrial or community plantation forests. This wood has fairly good basic wood properties with moderate density and strength (strength class III) (Lempang, 2014), but its durability is low (durability class IV) (Cahyono et al., 2015, Halawane, 2015). So quality improvement is required particularly its dimen- sional stability and durability against degrading organisms. Red jabon grows and spreads in most of the Central-Eastern part of Indonesia, such as in Sulawesi, Maluku and Papua (BPHW Lebak dan Tangerang, 2017). The standing stock of red jabon in Bua District, Luwu Regency was $5127 \mathrm{~m}^{3}$, with an average volume of $253.06 \mathrm{~m}^{3} /$ ha (Efendi et al., 2019).

Boron compounds such as borax $\left(\mathrm{Na}_{2} \mathrm{~B}_{4} \mathrm{O}_{7}\right)$ and boric acid $\left(\mathrm{H}_{3} \mathrm{BO}_{3}\right)$ are commonly used as wood preservatives because of their fungicides and insecticides ef-

${ }^{1}$ Date Received June 20, 2021, Date Accepted October 29, 2021

${ }^{2}$ Forest Products Department, Faculty of Forestry and Environment, IPB University, Jl. Ulin, Kampus IPB Darmaga, Bogor 16680, Jawa Barat, Indonesia

${ }^{3}$ Forestry Department, Faculty of Agriculture and Forestry, Universitas Darussalam Ambon, Jl. Waehakila Puncak Wara, Batu Merah, Ambon 97128, Maluku, Indonesia

† Corresponding author: Tekat Dwi CAHYONO (e-mail: tekatdwicahyono@gmail.com, ORCID: 0000-0002-3010-7656) 
Posttreatment Effects of Castor Bean Oil and Heating in Treated Jabon Wood on Boron Leaching,

Dimensional Stability, and Decay Fungi Inhibition

fects, but low toxicity to mammals (Yamauchi et al., 2007; Kartal et al., 2020). Boron compound increases the resistance of wood against brown-rot fungus (Fomitopsis palustris) and white rot fungus (Trametes versicolor) (Son et al., 2013). Brown rot fungi are more sensitive to boric acid than white rot fungi (Lesar and Humar, 2009). Boric acid can inhibit $\beta$-glucosidase production and the growth Paecilomyces variotii and Trichoderma fungi (Ang et al., 2011). Moreover, boric acid at concentration of $2 \%$ or more was effective for bed bug control (Sierras et al., 2018). This compound could significantly suppress the population of subterranean termites, Heterotermes indicola and Odontotermes sp. (Farid et al., 2015) and cause critical dysbiosis in cockroaches (Blattella germanica) (Jiang et al., 2021). However, boron preservative is easily leached by water that is not suitable for exterior uses (Salman et al., 2014). Boron in wood has radial and tangential diffusion coefficients under water leaching conditions, which are determined by the boron concentration ( $\mathrm{Ra}$ and Kim, 2006). Obanda et al. (2008) suggests the use of combined boron compounds with natural oil to overcome this problem. The natural oil caused more hydrophobic wood and can prevent boron leaching.

Castor bean oil is potential to be combined with boron compounds for wood protection. Castor bean oil is produced from the seed extract of Ricinus communis L. by a pressing process (Patel et al., 2016). According to Fatima et al. (2021), plant oils impregnation can create a hydrophobic barrier of water in woods. This less water access may prevent leaching of impregnated substance in wood. Moreover, castor bean oil can inhibit spore germination and mycelial growth of Lasiodiplodia theobromae fungi due to ricinoleic acid (Freire et al., 2013). Castor bean oil can control Tetranychus urticae (Ghorab and Ismail, 2017), Odontotermes obesus (Ahmed et al., 2014) and Coptotermes curvignathus termites (Abdulrahman et al., 2018).
The combination of heat treatment and plant oil impregnation has a good potential in wood protection. A combination of neem and sesame oils and heat treatment up to $200^{\circ} \mathrm{C}$ significantly improved the resistance of poplar wood against termites (Fatima et al., 2021). Some previous research also revealed that high temperature heating increased the dimensional stability of wood (Bekhta and Niemz, 2003; Sandberg et al., 2017), however it induced a darker wood color (Priadi et al., 2020). Oil-heat treatment at $180^{\circ} \mathrm{C}$ uniformly changed the color of Korean pine woods. The average lightness index $\left(L^{*}\right)$ and redness indexes $\left(a^{*}\right)$ increased, the average yellowness indexes $\left(b^{*}\right)$ were variable, while the average color differences $(\Delta E *)$ was only 18.4 (Lee et al., 2015). Heating temperatures between $100^{\circ} \mathrm{C}$ and $200^{\circ} \mathrm{C}$ affected the mechanical properties of wood due to the change of chemical components of wood, particularly hemicellulose (Kocaefe et al., 2008; Cahyono et al., 2020).

The application of boron compounds in wood preservation still needs improvement, mainly in leaching and outdoor uses problems. The combination of oil impregnation and heat treatment is potential to improve the drawback of boron preservation. Therefore, this research aimed to analyze the post-treatment effects of castor bean oil and heating in treated jabon wood on boron leaching, dimensional stability and the resistance against decay fungi.

\section{MATERIALS and METHODS}

This research was conducted at the workshop and laboratories at Division of Wood Quality Improvement Technology, Department of Forest Product Technology, Faculty of Forestry and Environment, IPB University. Wood samples were taken from 9 years tree of red jabon (Anthocephalus macrophyllus (Roxb.) Havil) that had $13 \mathrm{~m}$ height and $40 \mathrm{~cm}$ diameter. The red jabon logs were sawn into some $3 \mathrm{~cm}$ thick boards. 
Then the boards were kiln dried at $40^{\circ} \mathrm{C}$ to $15 \%$ moisture content. Furthermore, wood samples were made in some different sizes as described in Table 1.

Boric acid (AB), borax (B), and mixture of borax-boric acid (1:1 w/w) (ABB) were made as preservative solutions in $5 \%$ concentration each. In addition castor bean oil (Ricinus communis L.) (MJ) from Heansa Kimia store was used for impregnation to reduce preservative leaching and increase the protection against degrading organisms.

The impregnation was conducted in a pressure tank at $7 \mathrm{~kg} \mathrm{~cm}^{-2}$ for 4 hours. The first impregnation used

Table 1. The sample sizes for decay test and dimensional stability tests

\begin{tabular}{lc}
\hline \multicolumn{1}{c}{ Test } & Sample Size $(\mathrm{cm})$ \\
\hline \hline Leaching and dimensional stability test & $10 \times 2 \times 2$ \\
Fungal decay test & $5 \times 2.5 \times 1.5$ \\
\hline
\end{tabular}

boron preservatives. After re-drying to $15 \%$ moisture content, the second impregnation was applied using castor bean oil. Furthermore, the impregnation process was followed by heating at $80^{\circ} \mathrm{C}$ or $160^{\circ} \mathrm{C}$. This heat treatment was also applied to the samples without castor bean oil. The impregnation and heat treatment are presented in Table 2. Finally all the samples were conditioned in room temperature $\left( \pm 28^{\circ} \mathrm{C}\right)$.

Water absorption, leaching and dimensional stability test used the same samples. Wood samples were soaked in water for 2, 24 and 48 hours. The weight and dimensions of samples were measured before and after every soaking. Oven-drying at $103 \pm 2{ }^{\circ} \mathrm{C}$ for 48 hours followed every soaking time to get the oven dry weight and dimensional changes of the wood. The amount of leachant $(L)$ was determined based on the difference of oven dry weight before $(W o i)$ and after soaking (Wos). The water absorption value (WA) was

Table 2. Double impregnation and heat treatments

\begin{tabular}{ccccc}
\hline & Double Impregnation & & & \\
\hline Impregnant 1 & Concentration (\%) & Impregnant 2 & Heat & Treatment $\left({ }^{\circ} \mathrm{C}\right)$ \\
\hline \hline TB & - & TMJ & 80 & 5 \\
TB & - & TMJ & 160 & 5 \\
TB & - & MJ & 80 & 5 \\
TB & - & 160 & 5 \\
AB & 5 & MJ & 80 & 5 \\
AB & 5 & TMJ & 160 & 5 \\
AB & 5 & TMJ & 80 & 5 \\
AB & 5 & MJ & 160 & 5 \\
B & 5 & MJ & 80 & 5 \\
B & 5 & TMJ & 160 & 5 \\
B & 5 & TMJ & 80 & 5 \\
B & 5 & MJ & 160 & 5 \\
ABB & 5 & MJ & 80 & 5 \\
ABB & 5 & TMJ & 160 & 5 \\
ABB & 5 & TMJ & 80 & 5 \\
ABB & 5 & MJ & 160 & 5
\end{tabular}

Notes: $\mathrm{TB}=$ without boron, $\mathrm{AB}=$ boric acid, $\mathrm{B}=$ borax, $\mathrm{ABB}=$ mixture of borax-boric acid $(1: 1)$, $\mathrm{TMJ}=$ without castor bean oil, $\mathrm{MJ}=$ castor bean oil. 
Posttreatment Effects of Castor Bean Oil and Heating in Treated Jabon Wood on Boron Leaching,

Dimensional Stability, and Decay Fungi Inhibition

obtained from the difference between wet weight $(W s)$ and oven dry weight (Wos) of sample after each soaking. Equations 1 and 2 were used to calculate leachant (L) and water absorption (WA).

$$
\begin{gathered}
L=\frac{W o i-W o s}{W o i} \times 100 \\
W A=\frac{W s-W o s}{W o s} \times 100
\end{gathered}
$$

where:

$$
\begin{aligned}
& L=\text { leachant }(\%) \\
& W o i=\text { oven dry weight before soaking }(\mathrm{g}) \\
& W o s=\text { oven dry weight after soaking }(\mathrm{g}) \\
& W A=\text { water absorption }(\%) \\
& W S=\text { weight after soaking }(\mathrm{g}) \\
& W o s=\text { oven dry weight after soaking }(\mathrm{g})
\end{aligned}
$$

The dimensional stability was evaluated based on anti-swelling efficiency (ASE), shrinkage in tangential and radial directions. The ASE value was obtained from the volume swelling difference of control sample $(S W c)$ and treated sample $(S W t)$. The dimensional measurement was used to calculate wood shrinkage $(S)$ in tangential $(S t)$ and radial directions $(S r)$. The Equations 3, 4, 5, and 6 were used to calculate the volume swelling, ASE, dimensional shrinkage and $T / R$ shrinkage ratio of wood sample.

$$
\begin{gathered}
S W=\frac{V 2-V 1}{V 1} \times 100 \\
A S E=\frac{S W c-S W t}{S W c} \times 100 \\
S=\frac{D 1-D 2}{D 1} \times 100 \\
T / R=\frac{S t}{S r}
\end{gathered}
$$

where:

$$
\begin{aligned}
& S W=\text { volume swelling }(\%) \\
& V 2=\text { volume after soaking }\left(\mathrm{cm}^{3}\right) \\
& V 1=\text { volume before soaking }\left(\mathrm{cm}^{3}\right)
\end{aligned}
$$

$$
\begin{aligned}
& A S E=\text { anti-swelling efficiency }(\%) \\
& S W c=\text { volume swelling of control sample }(\%) \\
& S W t=\text { volume swelling of treated sample }(\%) \\
& S=\text { shrinkage }(\%) \\
& D 1=\text { dimension (tangential, radial) before drying }(\mathrm{cm}) \\
& D 2=\text { dimension (tangential, radial) after drying }(\mathrm{cm}) \\
& T / R=\text { tangential-radial shrinkage ratio } \\
& S t=\text { tangential shrinkage (\%) } \\
& S r=\text { radial shrinkage }(\%)
\end{aligned}
$$

Fungal decay test of wood based on Indonesian Standard, SNI 7207: 2014. Wood samples were oven dried at $80^{\circ} \mathrm{C}$ for 7 days and then exposed to Schizophyllum commune Fr. and Fomitopsis palustris in PDA (potato dextrose agar) medium for 12 weeks at room temperature $\left( \pm 28^{\circ} \mathrm{C}\right)$. Furthermore, all wood samples were cleaned from fungal mycelium and oven-dried again at $80^{\circ} \mathrm{C}$ for 7 days. The sample weight before and after fungal testing were determined and used to calculate the weight loss of wood sample using Equation 7.

$$
W L=\frac{W 1-W 2}{W 1} \times 100
$$

where:

$$
\begin{aligned}
& W L=\text { weight loss of sample }(\%) \\
& W 1=\text { weight of sample before the test }(\mathrm{g}) \\
& W 2=\text { weight of sample after the test }(\mathrm{g})
\end{aligned}
$$

The effects of boron preservative, castor bean oil, and heating on the durability and physical properties of wood were analyzed statistically using a completely randomize factorial design with three factors. Factor A was the preservation with 4 categories, namely boric acid $(\mathrm{AB})$, borax $(\mathrm{B})$, boric acid-borax $(\mathrm{ABB})$, and without boron preservative (TB). Factor B was oil impregnation with 2 categories, with and without castor bean oil (MJ and TMJ). Factor $\mathrm{C}$ was heat treatment with 2 two temperatures $\left(80^{\circ} \mathrm{C}\right.$ and $\left.160^{\circ} \mathrm{C}\right)$. This data 
analyses used Microsoft Excel 2019 and IBM SPSS Statistics 22.0. The analysis of variance (ANOVA) was conducted and followed with the Duncan test, when the ANOVA resulted a significant effect at $95 \%$ confidence interval.

\section{RESULTS and DISCUSSION}

\subsection{Water absroption}

Wood can absorb water from the environment due to its hygroscopic nature. Water absorption in red jabon wood increased from $108 \%$ to $176 \%$ with the soaking periods ( 2 to 48 hours). The water absorption of boric acid treated wood was less than that in un- treated ones. This because the presence of boric acid in the treated wood reduced the availability voids for water absoption. After 48 hours water soaking, boric acid $(\mathrm{AB})$ treatment reduced water absorption of red jabon wood to $78 \%$, which was lower than that of the borax (B) and boric acid-borax (ABB) treatments, which were $158 \%$ and $161 \%$ respectively (Fig. 1). The higher water absorption of borax treated wood than boric acid treated one because of the difference in higroscopicity, as reported by (Toker, 2007) that the hygroscopicity of borax compounds was higher than that of boric acid.

Based on the analysis of variance (Table 3) at the $95 \%$ confidence interval, the interaction of boron preservation, castor bean oil impregnation and heat treat-

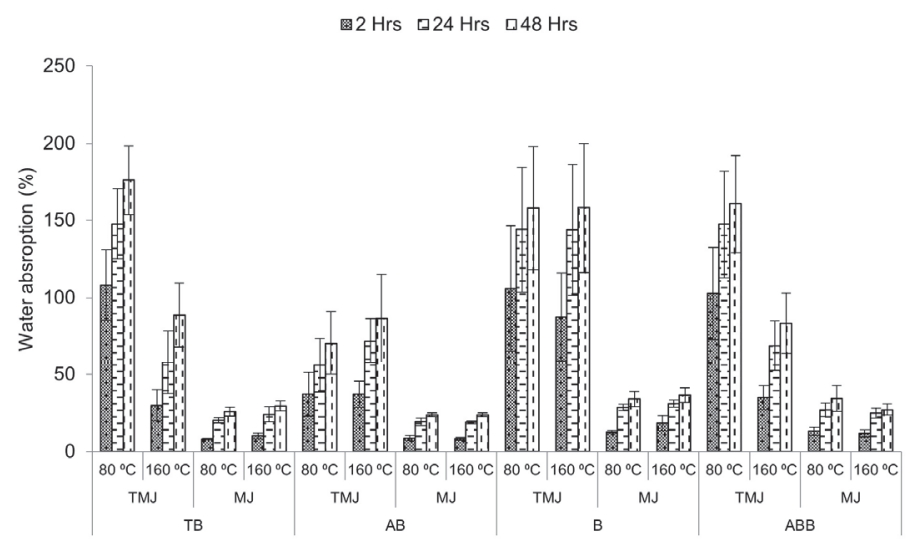

Fig. 1. Water absroption of treated red jabon wood with boric acid (AB), borax (B), borax-boric acid (ABB), without boron $(\mathrm{TB})$, castor bean oil $(\mathrm{MJ})$, without castor bean oil $(\mathrm{TMJ})$, and heating temperatures $(80$ and $\left.160^{\circ} \mathrm{C}\right)$.

Table 3. Significance values from analyses of variance

\begin{tabular}{|c|c|c|c|c|c|c|c|c|}
\hline Treatments & $\begin{array}{c}\text { Water } \\
\text { Absorbtion }\end{array}$ & Leaching & ASE & T-Shrinkage & R-Shrinkage & $\begin{array}{c}\text { T/R Shrinkage } \\
\text { Ratio }\end{array}$ & White Rot & Brown Rot \\
\hline Boron & $0.000(* *)$ & $0.000(* *)$ & $0.000(* *)$ & $0.000(* *)$ & $0.000(* *)$ & 0.099 (ns) & $0.000(* *)$ & $0.000(* *)$ \\
\hline Castor bean oil & $0.000(* *)$ & $0.000(* *)$ & $0.000(* *)$ & $0.000(* *)$ & $0.000(* *)$ & 0.344 (ns) & $0.000(* *)$ & $0.195(\mathrm{~ns})$ \\
\hline Heating & $0.000(* *)$ & 0.915 (ns) & $0.000(* *)$ & $0.007(* *)$ & $0.002(* *)$ & 0.865 (ns) & $0.084(\mathrm{~ns})$ & $0.242(\mathrm{~ns})$ \\
\hline Boron*Castor bean oil & $0.000(* *)$ & $0.000(* *)$ & $0.000(* *)$ & $0.000(* *)$ & $0.000(* *)$ & $0.011(*)$ & $0.002(* *)$ & $0.000(* *)$ \\
\hline Boron*Heating & $0.000(* *)$ & $0.001(* *)$ & $0.005(* *)$ & $0.243(\mathrm{~ns})$ & $0.006(* *)$ & $0.00(* *)$ & $0.000(* *)$ & $0.000(* *)$ \\
\hline Castor bean oil*Heating & $0.000(* *)$ & $0.020(*)$ & $0.012(*)$ & 0.757 (ns) & $0.219(\mathrm{~ns})$ & 0.154 (ns) & $0.000(* *)$ & $0.000(* *)$ \\
\hline Boron*Castor bean oil*Heating & $0.000(* *)$ & $0.000(* *)$ & $0.004(* *)$ & $0.003(* *)$ & $0.688(\mathrm{~ns})$ & $0.002(* *)$ & 0.687 (ns) & $0.001(* *)$ \\
\hline
\end{tabular}


Posttreatment Effects of Castor Bean Oil and Heating in Treated Jabon Wood on Boron Leaching,

Dimensional Stability, and Decay Fungi Inhibition

ments significantly affected the water absorption of red jabon wood. The following Duncan test (Table 4) showed that the impregnation of castor bean oil significantly reduced the water absorption of red jabon wood to $26 \%$. The water absorption of boron treated woods also reduced by $1 / 3$ or $1 / 5$ when post-treated with castor bean oil. This is because castor bean is hydrophobic. Tomak et al. (2011) also stated that natural oil is hydrophobic and potential to be used in reducing water absorption of wood.

Heating at $160^{\circ} \mathrm{C}$ significantly reduced water absorption of red jabon wood to $89 \%$, which was lower

Table 4. Duncan test results of some tested variables in different treatments

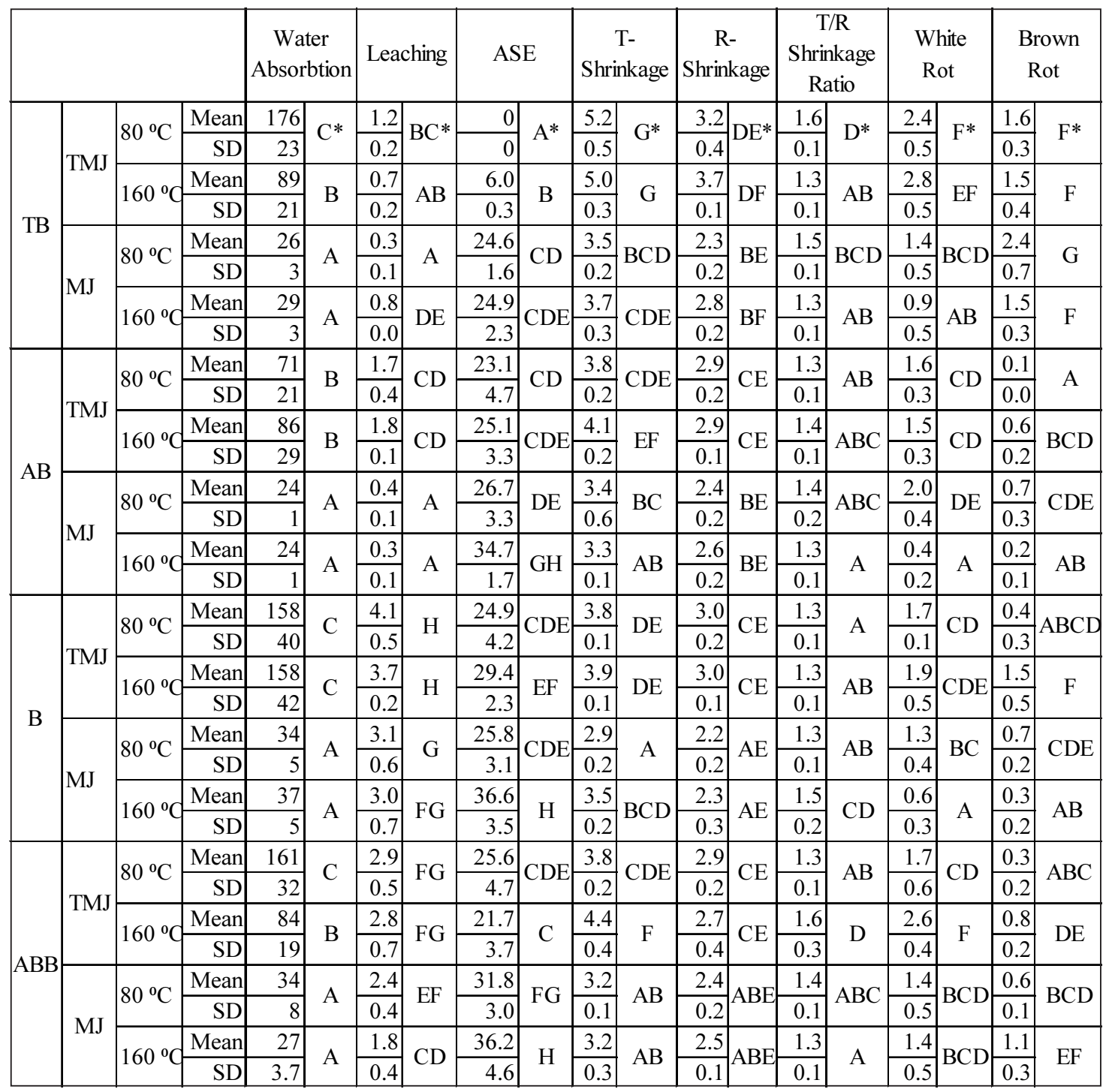

*Groups with the same letters in each column indicates that there is no statistical difference $(\rho<0.005)$ between the treatments according to the Duncan's multiple range test 
than that of heating at $80^{\circ} \mathrm{C}(176 \%)$ (Fig. 1). However, heating at $160^{\circ} \mathrm{C}$ did not affect the water absorption of boron treated wood and castor bean oil treated wood. The heat treatment effect on wood hygroscopicity have been reported in some previous studies. Chang et al. (2019) revealed that heating at $200^{\circ} \mathrm{C}$ reduced the hygroscopicity of wood due to hemicellulose degradation in wood. Previously, Bekhta and Niemz (2003) also reported that the -OH group in hemicellulose decreased with the increase of heating temperature, which then significantly affected the hygroscopicity of wood.

\subsection{Leaching evaluation}

This research revealed that leaching of boron treated red jabon wood had a higher leaching value than the untreated wood, namely $1.2 \% \pm 0.2 \%$ (Fig. 2). This supported Caldeira (2010) that boron compounds had high water solubility and could be washed by water. The analysis of variance (Table 3 ) at $95 \%$ confidence interval showed that there was an interaction effect of boron treatment, castor bean oil and heating on the leaching in red jabon wood. The following Duncan test (Table 4) showed that the leaching in boric acid impregnation (ABTMJ80) treatment was $1.7 \% \pm 0.4 \%$, wich was lower than that in borax impregnation (BTMJ80) and borax-boric acid (ABBTMJ80) impregnations $(4.1 \% \pm 0.5 \%$ and $2.9 \% \pm 0.5 \%$ respectively). This was in accordance with Toker (2007) that boric acid was less hygroscopic than borax.

The leaching in the treated samples of ABTMJ160, BTMJ160, and ABBTMJ160 were not significantly different from that of ABTMJ80, BTMJ80, and ABBTMJ80 respectively. This indicated that heating $160^{\circ} \mathrm{C}$ could not reduce the leaching of boric acid, borax and borax-boric acid preservatives in red jabon wood. On the other hand, the castor bean oil treatment (ABMJ80, BMJ80, and ABBMJ80) reduced the leaching value of boron treated wood (ABTMJ80, BTMJ80, and ABBTMJ80). According to Ogunniyi (2006), castor bean oil has hydrophobic nature. Thus this oil can reduce water in the leaching of boron preservative. Therefore, double impregnation with boron preservative and castor bean oil can make the treated wood reliable for external uses.

웅 2 Hrs $\square 24 \mathrm{Hrs}$ m48 Hrs

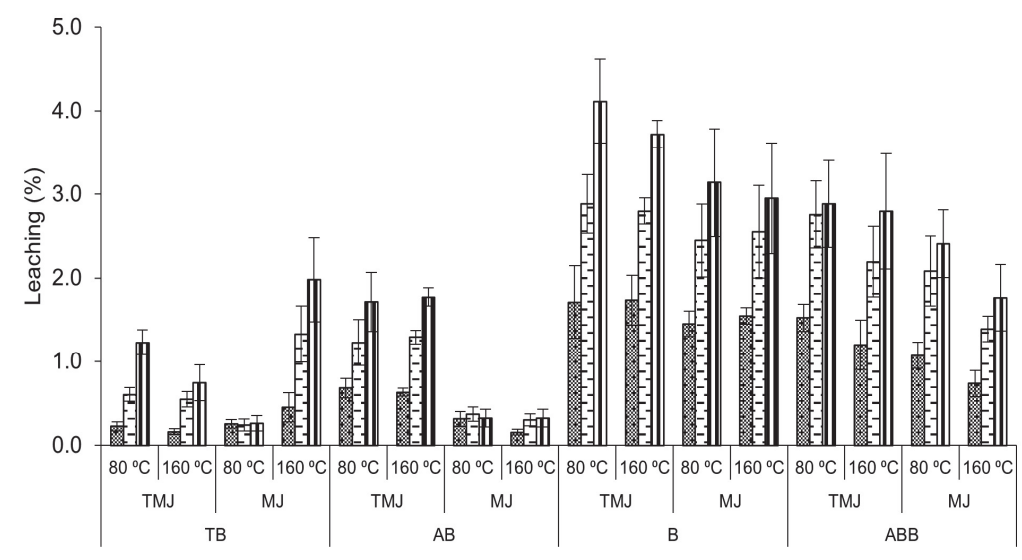

Fig. 2. Leaching of treated red jabon wood with boric acid (AB), borax (B), borax-boric acid (ABB), without boron (TB), castor bean oil (MJ), without castor bean oil (TMJ), and heat temperatures $\left(80^{\circ} \mathrm{C}\right.$ and $\left.160^{\circ} \mathrm{C}\right)$. 
Posttreatment Effects of Castor Bean Oil and Heating in Treated Jabon Wood on Boron Leaching,

Dimensional Stability, and Decay Fungi Inhibition

\subsection{Dimensional stability of wood}

Dimensional stability represents the ability of wood to withstand dimensional changes due to the changes of moisture content. Wood is a lignocellulose material which is hygroscopic that can absorb and release water. The swelling of wood is equivalent to the moisture increase in the cell wall (Bowyer et al., 2007; Coto et al., 2015). This study generally revealed that boron preservative, castor bean oil and heating $160^{\circ} \mathrm{C}$ treatments resulted positive values of anti-swelling efficiency (ASE) (Fig. 3), which indicated a dimensional stability improvement of red jabon wood.

The analysis of variance (Table 3 ) at a $95 \%$ confidence interval revealed that there was an interaction effect of boron, castor bean oil and heating on the ASE value of red jabon wood. The Duncan test (Table 4) showed that the impregnated red jabon wood by castor bean oil especially that combined with heating at $160^{\circ} \mathrm{C}$ had a significant higher $A S E$ value than that of boron-treated wood. According to Tomak et al. (2011) impregnated oil in wood caused hydrophobic properties in wood cells. The oil resisted the entry of water into the wood and reduced its volume swelling.

Impregnation of boric acid (ABTMJ80), borax
(BTMJ80) or borax-boric acid (ABBTMJ80) also caused positive $A S E$ value and higher than heat treatment at $160^{\circ} \mathrm{C}$ (TBTMJ160). It was in accordance with the report of Candan et al. (2011) that borax-boric acid treatment resulted a lower thickness swelling of oriented strand board than the untreated one. Furthermore, heating at $160^{\circ} \mathrm{C}$ (TBTMJ160) resulted in a positive $A S E$, which indicated a less swelling value of red jabon wood than heating at $80^{\circ} \mathrm{C}$ (TBTMJ80). This could be related to the changes of crystallinity and chemicals component in the wood. As the report of Kim et al. (2019) that heat treatment at 100 and $200^{\circ} \mathrm{C}$ increased the crystallinity of wood cellulose. In addition, Cheng et al. (2016) revealed that heat treatment caused the degradation of hemicellulose in Chinese fir wood.

This research showed that treated red jabon wood with boron, castor bean oil and heating $160^{\circ} \mathrm{C}$ had lower tangential and radial shrinkages than that of the untreated control wood (tangential shrinkage $=5.18 \%$; radial shrinkage $=3.23 \%$ ) (Fig. 4). These shrinkage values were slightly higher than that were reported by Lempang (2014), the tangential and radial shrinkage of red jabon wood were $5.41 \%$ and $3.03 \%$ respectively.

The tangential shrinkage of red jabon wood was sig-

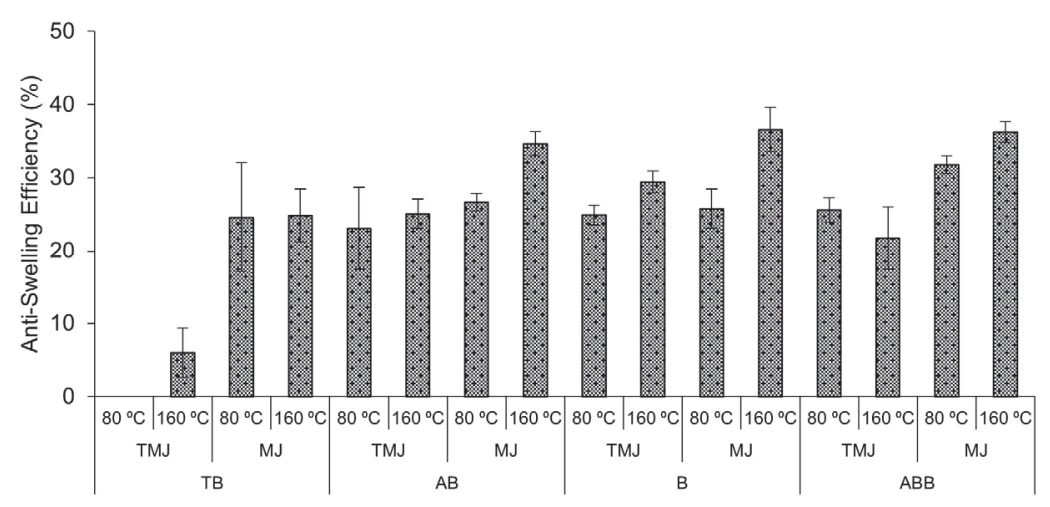

Fig. 3. The Anti-swelling efficiency of treated red jabon wood with boric acid (AB), borax (B), borax-boric acid (ABB), without boron (TB), castor bean oil (MJ), without bean castor bean oil (TMJ), and heat temperatures $\left(80^{\circ} \mathrm{C}\right.$ and $\left.160^{\circ} \mathrm{C}\right)$. 


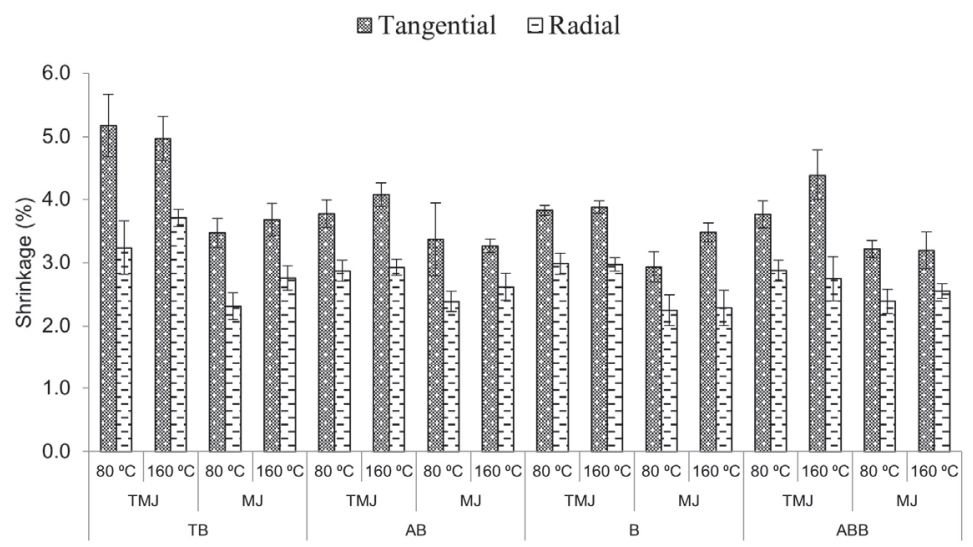

Fig. 4. Tangential and radial shrinkage of treated red jabon wood with boric acid (AB), borax (B), borax-boric acid (ABB), without boron (TB), castor bean oil (MJ), without bean castor bean oil (TMJ), and heat temperatures $\left(80^{\circ} \mathrm{C}\right.$ and $\left.160^{\circ} \mathrm{C}\right)$.

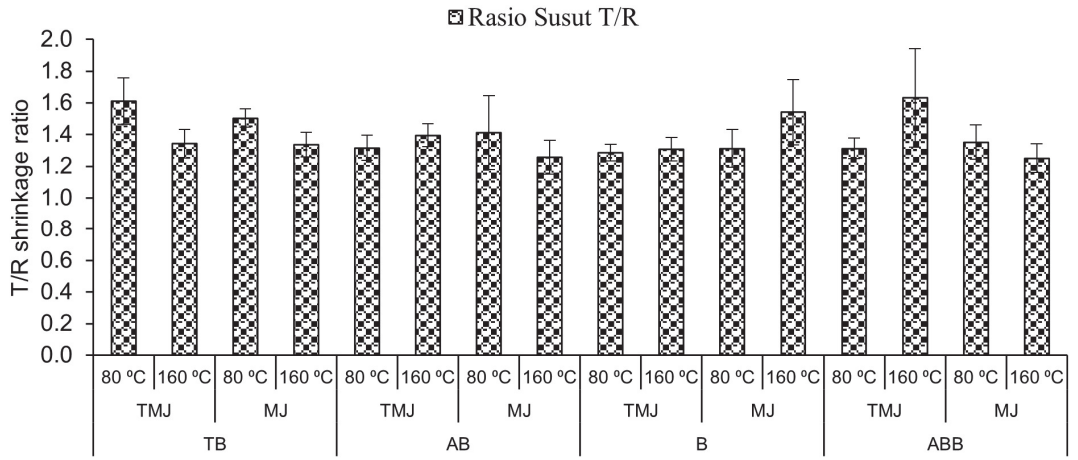

Fig. 5. Tangential-radial shrinkage ratio $(T / R)$ of treated red jabon wood with boric acid (AB), borax (B), borax-boric acid $(\mathrm{ABB})$, without boron $(\mathrm{TB})$, castor bean oil $(\mathrm{MJ})$, without bean castor bean oil (TMJ), and heat temperatures $\left(80^{\circ} \mathrm{C}\right.$ and $\left.160^{\circ} \mathrm{C}\right)$.

nificantly affected by the interaction of boron compounds, castor bean oil and heating, while the radial shrinkage was affected by interaction between boron compounds and heating, and the interaction between boron compound and castor bean oil (Table 3). Boron treatment and castor bean oil treatment significantly reduced tangential shrinkage at a $95 \%$ confidence interval, but not significantly reduced radial shrinkage of red jabon wood. This could be caused by the resistance by the ray cells of wood that oriented in the radi- al direction. Post-treatment of castor bean oil significantly reduced the tangential shrinkage of boron treated wood.

The shrinkage ratio of tangential and radial directions (T/R shrinkage ratio) is an indicator of wood dimensional stability. This research showed that all the treatments generally reduced the $T / R$ value of red jabon wood (Fig. 5). This $\mathrm{T} / \mathrm{R}$ value reduction indicated better dimensional stability of the wood. According to Basri et al. (2009), wood with a T/R shrinkage ratio 
Posttreatment Effects of Castor Bean Oil and Heating in Treated Jabon Wood on Boron Leaching,

Dimensional Stability, and Decay Fungi Inhibition

of less than 2.0 will have less drying defects than the wood with a $\mathrm{T} / \mathrm{R}$ shrinkage ratio of more than 2.0 .

The variance analysis at a $95 \%$ confidence interval revealed that there was an interaction effect of boron preservatives, castor bean oil treatment and heating on the $T / R$ shrinkage ratio of red jabon wood (Table 3 ). The following Duncan test revealed that boron preservatives (boric acid, borax, and borax-boric acid) treatment and castor bean oil treatment significantly reduced the $T / R$ shrinkage ratio of red jabon wood (Table 4). In addition, heat treatment at $160^{\circ} \mathrm{C}$ caused a significant lower $\mathrm{T} / \mathrm{R}$ shrinkage ratio of red jabon wood than that of heat treatment at $80^{\circ} \mathrm{C}$.

\subsection{Wood decay resistance against fungi}

The wood decay resistance against white rot and brown rot fungi ( $S$. commune Fr. and $F$. palustris) were expressed in wood weight loss (Figures 6 and 7). Boron preservatives (ABTMJ80, BTMJ80, and ABBTMJ80), castor bean oil and heat treatments affected the decay resistance of red jabon wood against white rot and brown rot fungi.

Fig. 6 shows that the highest weight loss value occurred in the wood without preservative boron and

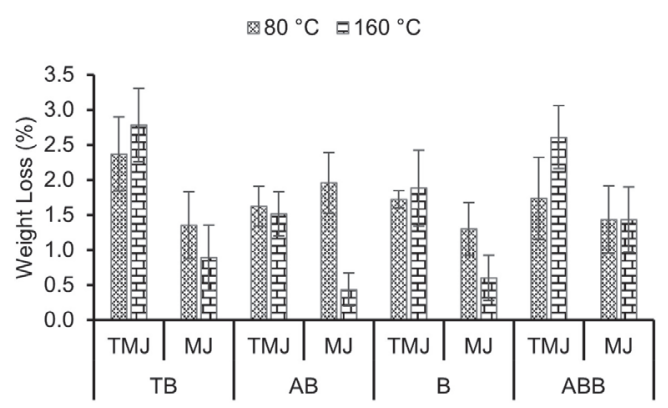

Fig. 6. Weight loss of treated red jabon wood in white rot fungal test: The treatments are $\mathrm{TB}=$ without boron, $\mathrm{AB}=$ boric acid, $\mathrm{B}=$ borax, $\mathrm{ABB}=$ borax-boric acid, $\mathrm{TMJ}=$ without castor bean oil, $\mathrm{MJ}=$ castor bean oil, and heat temperatures $\left(80^{\circ} \mathrm{C}\right.$ and $\left.160^{\circ} \mathrm{C}\right)$. castor bean oil, which was heated at $160^{\circ} \mathrm{C}$ (TBTMJ160) with a value of $2.78 \%$, while the lowest weight loss value was in wood impregnated with boric acid and castor bean oil, which was heated at $160^{\circ} \mathrm{C}$ (ABMJ160) with a weight loss value of $0.44 \%$.

The analysis of variance (ANOVA) at the $95 \%$ confidence interval showed that the interaction of boron and castor bean oil (MJ) treatments, the interaction of boron and heat treatments, as well as the interaction of $\mathrm{MJ}$ and heat treatments had significant effects on the wood weight loss in this white rot fungal test (Table 3). Furthermore, the Duncan test showed that the weight loss of impregnated wood with boron preservatives $(\mathrm{AB}, \mathrm{B}$, and $\mathrm{ABB})$ or castor bean oil $(\mathrm{MJ})$ were significantly lower than that in untreated red jabon wood (TBTMJ80) and that in without castor bean oil (TMJ). Moreover, post-tretament of castor bean oil and heating at $160^{\circ} \mathrm{C}$ following boric acid or borax preservation (ABMJ160 or BMJ160) resulted in a significant lower weight loss of red jabon wood compared to the other treatements in this research. This mean that castor bean oil and heating at $160^{\circ} \mathrm{C}$ increased the protection of boric acid and borax in wood against white rot fungi. This complemented the previous research by Tomak et al. (2011) that the combi-

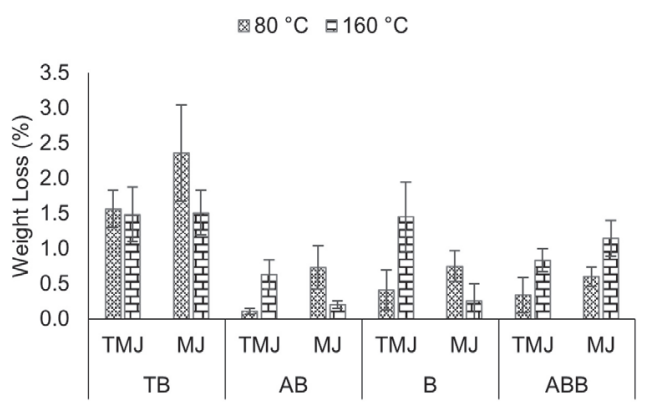

Fig. 7. Weight loss of treated red jabon wood in brown rot fungal test: The treatments are $\mathrm{TB}=$ without boron, $\mathrm{AB}=$ boric acid, $\mathrm{B}=$ borax, $\mathrm{ABB}=$ borax-boric acid, $\mathrm{TMJ}=$ without castor bean oil, $\mathrm{MJ}=$ castor bean oil, and heat temperatures $\left(80^{\circ} \mathrm{C}\right.$ and $\left.160^{\circ} \mathrm{C}\right)$. 
nation of boron compounds with natural oils such as peanut oil, soybean oil, or corn has the potential to produce a synergistic effect against fungal attack indicated by less weight loss compared to untreated wood. On the other hand, the heat treatment at $160^{\circ} \mathrm{C}$ without impregnation of boron and castor bean oil increased the weight loss of red jabon wood by white rot fungal attack.

The effect of castor bean oil (MJ) on reducing white rot fungi attack was due to the presence of toxic compounds against fungi. Momoh et al. (2012) revealed by spectrophotometric analysis and found the presence of saponins, tannins, phenols, cyanogenic glycosides and flavonoids in Ricinus communis. Previously Lattanzio et al. (2006) also reported that phenolic substances were secondary metabolites in plants that involved in defense mechanisms against fungal pathogens.

Boron treatment increased the resistance of red jabon wood against brown rot fungi (F. palustris) which was indicated by less wood weight loss than that in control sample (Fig. 7). Statistical analysis (Table 3) showed the weight loss of red jabon wood due to brown rot fungi attack was significantly affected by the interaction factor of boron preservative, castor bean oil and heat treatments at $95 \%$ confidence interval. The Duncan test revealed that boron treatment (ABTMJ80, BTMJ80 and ABBTMJ80) caused a significant lower weight loss than that in untreated wood (TBTMJ80). This because boron compounds has antifungal effect as reported by Lesar and Humar (2009).

The post-treatment of castor bean oil and heating at $160^{\circ} \mathrm{C}$ following boron preservation (ABMJ160 and BMJ160) significantly improved the resistance of red jabon wood against brown rot fungi ( $F$. palustris), which were indicated by a significant lower weight loss than that in untreated wood (TBTMJ80). However the results of ABMJ160 and BMJ160 treatments were not significantly different from that of single boron treatment (ABTMJ80 and BTMJ80 respectively). This study complements the previous study by Lyon et al. (2007), a combination of boric acid treatment with hot flaxseed oil could protect Cryptomeria japonica and Fagus crenata woods against brown rot fungus (F. palustris).

\section{CONCLUSION}

The treatment of boron compounds (boric acid, borax and borax-boric acid), castor bean oil and heating generally affected the physical properties and decay resistance of red jabon wood. Boric acid treated wood had lower water absorption than other boron treated wood. Water absorption of red jabon wood also reduced significantly by heating at $160^{\circ} \mathrm{C}$ as well as by castor bean oil treatment. The treatment of boron compounds, heating $160^{\circ} \mathrm{C}$, and castor bean oil increased dimensional stability of red jabon wood. Post-treatment of castor bean oil and heating $160^{\circ} \mathrm{C}$ significantly reduced water absorption and leaching of boron preservation and resulted the best dimensional stability improvement of red jabon wood.

Boron compounds increased the decay resistance of red jabon wood against $S$. commune and $F$. palustris. As well as heating $160^{\circ} \mathrm{C}$ improved the decay resistance against $F$. palustris. Post-treatement of castor bean oil and heating $160^{\circ} \mathrm{C}$ following boric acid or borax preservation resulted in better decay resistance against tested white rot and brown rot fungi.

\section{REFERENCES}

Abdulrahaman, A.A., Ajiboye, P.O., Aderemi, M.O., Sahli, A.A.A., Alaraidh, I.A. 2018. Comparative pesticidal properties of Jatropha curcas, Jatropha gossypifolia and Ricinus communis on termite and fungal infected woods. The Journal of Indian Botanical Society 97(3 and 4): 109-118. 
Posttreatment Effects of Castor Bean Oil and Heating in Treated Jabon Wood on Boron Leaching,

Dimensional Stability, and Decay Fungi Inhibition

DOI : 10.5958/2455-7218.2018.00003.7

Ahmed, S., Fatima, R., Hassan, B. 2020. Evaluation of different plant derived oils as wood preservatives against subterranean termite Odontotermes obesus. Maderas. Ciencia y tecnología 22(1): 109-120.

Ahmed, S., Fatima, R., Nisar, M., Hassan, B. 2014. Evaluation of castor bean oil on Acacia nilotica as wood preservative against Odontotermes obesus (Ramb.)(Termitidae: Isoptera). International Wood Products Journal 5(1): 5-10.

Ang, S.S., Salleh, A.B., Bakar, F.A., Yusof, N.A., Zaman, M.Z., Heng, L.Y. 2011. Effect of boric acid on the growth and production of $\beta$-glucosidase in Paecilomyces variotii. African Journal of Microbiology Research 5(17): 2451-2454.

Basri, E., Saefudin, Rulliaty, S., Yuniarti, K. 2009. Drying conditions for 11 potential ramin substitutes. Journal of tropical forest science: 328-335.

Bekhta, P., Niemz, P. 2003. Effect of high temperature on the change in color, dimensional stability and mechanical properties of spruce wood. Holzforschung 57(5): 539-546.

BPHW Lebak dan Tangerang. 2017. Cultivation of Jabon (Anthocephalus macrophyllus). Dinas Lingkungan Hidup dan Kehutanan Provinsi Banten.

Bowyer, J.L., Shmulsky, R., Haygreen, J.G. 2007. Forest Products and Wood Science: An Introduction. Wiley-Blackwell Publishing, Ames. Iowa (US). Cahyono, T.D., Darmawan, W., Iswanto, A. H., Priadi, T. 2020. Flexural properties of heat-treatment samama (Anthocephalus macrophyllus) wood impregnated by boron, methyl methacrylate. Journal of the Korean Wood Science and Technology 48(1): 76-85.

Cahyono, T.D., Wahyudi, I., Priadi, T., Febrianto, F., Darmawan, W., Bahtiar, E.T., Ohorella, S., Novriyanti, E. 2015. The quality of 8 and 10 years old samama wood (Anthocephalus macrophyllus). Journal of the Indian Academy of Wood Science 12(1): 22-28.
Caldeira, F. 2010. Boron in wood preservation. A review in its physico-chemical aspects. Silva Lusitana 18(2): 179-196.

Candan, Z., Ayrilmis, N., Akbulut, T. 2011. Dimensional stability performance of fire retardant treated veneer-oriented strandboard composites. Bioresources 6(1): 308-316.

Chang, Y.-S., Han, Y., Eom, C.-D., Jeon, S., Yeo, H. 2019. Hygroscopic property of heat treated yellow poplar (Liriodendron tulipifera) wood. Journal of the Korean Wood Science and Technology 47(6): 761-769.

Cheng, S., Huang, A. Wang, S., Zhang, Q. 2016. Effect of different heat treatment temperatures on the chemical composition and structure of Chinese fir wood. Bioresources 11(2): 4006-4016.

Coto, Z., Wahyudi, I., Hadiyanne, A. 2015. Improving Wood Quality through Phisical Properties Enhancement for Fast-Growing and Small-Diameter Timber. IPB Press, Bogor(ID).

Efendi, D., Rosdayanti, A., Ahmad, A. 2019. Identifying the potential of jabon merah (Anthocephalus marcophyllus) in Bua Subdistrict, Luwu Regency. Jurnal Penelitian Kehutanan Bonita 1(2): 23-30.

Farid, A., Zaman, M., Saeed, M., Khan, M., Shah, T.B. 2015. Evaluation of boric acid as a slow-acting toxicant against subterranean termites (Heterotermes and Odontotermes). Journal of Entomology and Zoology Studies 3(1): 213-216.

Fatima, Z., Ahmed, S., Hassan, B. 2021. Combined effects of neem (Azadirachta indica) and sesame (Sesamum indicum) oil as a wood preservative on subterranean termites in the field. Maderas. Ciencia y tecnología 23. http://dx.doi.org/10.4067/s0718$221 \times 2021000100435$

Freire, M.G.M., de Souza, C.L.M., Portal, T.P., Machado, R.M.A., dos Santos, P.H.D., Mussi-Dias, V. 2013. Effect of castor bean oil on post harvest fungal pathogen of coconut: Lasiodiplodia theobromae. 
Journal of Plant Physiology \& Pathology 1(3): 1-7. Ghorab, S.A., Ismail, M.S. 2017. Possible acaricidal activity of Jatropha curcas and Ricinus communis seed oils on Tetranychus urticae. Acarines 11(1): $57-63$.

Halawane, J.E. 2015. Red Jabon, Anthocephalus macrophyllus (Roxb.) Havil Business Prospect: Solutions for Future Wood Needs. Balai Penelitian Kehutanan Manado, Badan Penelitian Pengembangan dan Inovasi.

Kartal, S.N., Terzi, E., Yoshimura, T. 2020. Performance of fluoride and boron compounds against drywood and subterranean termites and decay and mold fungi. Journal of Forestry Research 31(4): 1425-1434.

Kim, A., Kim, N.H. 2019. Effect of particle size and heat treatment on crystalline properties of wood cellulose. Wood Engineering 47(3): 299-310.

Kocaefe, D., Shi, J.L., Yang, D.-Q., Bouazara, M. 2008. Mechanical properties, dimensional stability, and mold resistance of heat-treated jack pine and aspen. Forest Products Journal 58(6): 88-93.

Jiang, M., Dong, F., Pan,X., Zhang, Y., Zhang, F. 2021. Boric acid was orally toxic to different instars of Blattella germanica (L.) (Blattodea: Blattellidae) and caused dysbiosis of the, gut microbiota, Pesticide Biochemistry and Physiology 172: 104756. https://doi.org/10.1016/j.pestbp.2020.104756.

Lattanzio, V., Lattanzio, V.M., Cardinali, A. 2006. Role of phenolics in the resistance mechanisms of plants against fungal pathogens and insects. Phytochemistry: Advances in research 661(2): 23-67.

Lee, W.H., Lim, H.M., Kang, H.Y. 2015. The color change of korean pine specimens oil-heat-treated at 180 and $200^{\circ} \mathrm{C}$. Journal of the Korean Wood Science and Technology 43(4): 438-445.

Lempang, M. 2014. Basic properties and potential uses of red jabon wood. Jurnal Penelitian Kehutanan Wallacea 3(2): 163-175.
Lesar, B., Humar, M. 2009. Re-evaluation of fungicidal properties of boric acid. European Journal of Wood and Wood Products 67(4): 483.

Lyon, F., Thevenon, M.-F., Hwang, W.-J., Imamura, Y., Gril, J., Pizzi, A. 2007. Effect of an oil heat treatment on the leachability and biological resistance of boric acid impregnated wood. Annals of Forest Science 64(6): 673-678.

Momoh, A.O., Oladunmoye, M., Adebolu, T. 2012. Evaluation of the antimicrobial and phytochemical properties of oil from castor seeds (Ricinus communis Linn). Bulletin of Environment, Pharmacology and Life Sciences 1(10): 21-27.

Obanda, D.N., Shupe, T.F., Barnes, H.M. 2008. Reducing leaching of boron-based wood preservatives -A review of research. Bioresource Technology 99(15): 7312-7322.

Ogunniyi, D.S. 2006. Castor oil: a vital industrial raw material. Bioresource Technology 97(9): 1086-1091.

Patel, V.R., Dumancas, G.G., Viswanath, L.C.K., Maples, R., Subong, B.J.J. 2016. Castor oil: Properties, uses, and optimization of processing parameters in commercial production. Lipid insights 9: LPI. S40233.

Priadi, T., Orfian, G., Cahyono, T.D., Iswanto, A.H. 2020. Dimensional stability, color change, and durability of boron-MMA treated red jabon (Antochephalus macrophyllus) wood. Journal of the Korean Wood Science and Technology 48(3): 315-325.

Ra, J.B., Kim, G.H. 2006. Evaluation of diffusibility of boron in wood under water leaching conditions. Journal of the Korean Wood Science and Technology 34(5): 98-103.

Salman, S., Pétrissans, A., Thévenon, M.F., Dumarçay, S., Perrin, D., Pollier, B., Gérardin, P. 2014. Development of new wood treatments combining boron impregnation and thermo modification: effect of additives on boron leachability. European Journal of Wood and Wood Products 72(3): 355-365. 
Posttreatment Effects of Castor Bean Oil and Heating in Treated Jabon Wood on Boron Leaching,

Dimensional Stability, and Decay Fungi Inhibition

Sandberg, D., Kutnar, A., Mantanis, G. 2017. Wood modification technologies-a review. iForestBiogeosciences and Forestry 10(6): 895-908.

Sierras, A., Wada-Katsumata, A., Schal, C. 2018. Effectiveness of boric acid by ingestion, but not by contact, against the common bed bug (Hemiptera: Cimicidae). Journal of Economic Entomology 111(6): 2772-2781. https://doi.org/10.1093/jee/toy260

Son, D.W., Kang, M.R., Lee, D.H., Park, S.B. 2013. Decay resistance and anti-mold efficacy of wood treated with fire retardants. Journal of the Korean Wood Science and Technology 41(6): 559-565.

Toker, H. 2007. Determination of the Impact of Boron Compounds on Some Physical, Mechanical and
Biological Properties of Wooden Materials, Gazi University, Institute of Physical Sciences, PhD Thesis, September, Ankara.

Tomak, E.D., Viitanen, H., Yildiz, U.C., Hughes, M. 2011. The combined effects of boron and oil heat treatment on the properties of beech and Scots pine wood. Part 2: Water absorption, compression strength, color changes, and decay resistance. Journal of Materials Science 46(3): 608-615.

Yamauchi, S., Sakai, Y., Watanabe, Y., Kubo, M.K., Matsue, H. 2007. Distribution of boron in wood treated with aqueous and methanolic boric acid solutions. Journal of Wood Science 53(4): 324-331. 